Molecular and Cellular Biochemistry 73: $69-76$ (1987)

(C) Martinus Nijhoff Publishers, Boston. Printed in the Netherlands

Original Article

\title{
Interaction of snake venom cardiotoxin (a membrane-disruptive polypeptide) with human erythrocytes
}

\author{
Yee-Hsiung Chen ${ }^{1,2}$, Ruey-Fen $\mathrm{Liou}^{2}$, Chien-Tsung $\mathrm{Hu}^{1}$, Chung-Ching Juan ${ }^{1}$ and Jen Tsi Yang ${ }^{3}$ \\ ${ }^{1}$ Institute of Biochemical Sciences, National Taiwan University and ${ }^{2}$ Institute of Biological Chemistry, \\ Academia Sinica, Taipei, Taiwan 107, China; \\ ${ }^{3}$ Cardiovascular Research Institute, University of California, San Francisco, CA 94143, USA
}

Keywords: cardiotoxin, membrane-disruptive polypeptide, red blood cells

\begin{abstract}
The action of $7.2 \mu \mathrm{M}$ cardiotoxin on $0.25 \%$ human erythrocytes in a plasma extender solution was studied by the interaction of toxin with intact red blood cells and subsequent hemolysis of the cells. The binding of toxin to cells was completed within $10 \mathrm{~min}$, whereas the membrane rigidity was weakened in a non-lytic period for about $25 \mathrm{~min}$. The toxin molecules bound almost exclusively to the membrane. The bound toxin could not be liberated with either $0.5 \%$ Triton X-100 or $0.1 \mathrm{~N} \mathrm{NaOH}$. The degree of binding was slightly reduced in the presence of $10 \mathrm{mM}$ mono- and divalent inorganic salts. The action of toxin might weaken the in situ association of several proteins that are linked with band 3 protein of the membrane, thus making the cells fragile and altering the shape of the cell to a smooth sphere.
\end{abstract}

\section{Introduction}

Cardiotoxin (CTX) of snake venom is nonneurotoxic; it acts on cell membranes of different origins. CTX primarily induces cardiac arrest but also causes muscle contraction, membrane depolarization and cytolysis (1). Thus, it has been described as a cytoxin, a cytolysin, a direct lytic factor, a membrane-active polypeptide or a membrane-disruptive polypeptide $(2-5)$. CTX in the venom of Taiwan cobra (Naja naja atra) is a basic polypeptide of 60 amino acid residues with an isoelectric point of 10.8 (6). Its biological activities have intuitively been ascribed to its basicity. However, CTX can intercalate into liposomes and thereby weaken the hydrophobic interactions between hydrocarbon chains in the lipid bilayer $(7,8)$. Thus, hydrophilic interactions of basic amino acid residues of CTX with the membrane may be a necessary but not sufficient condition for membrane disintegration.

The molecular mechanism of CTX-induced hemolysis is still obscure, although CTX is known to affect the activities of several membrane-bound enzymes; for instance, treatment of osmotic ghosts of RBC markedly increased the activities of glyceraldehyde-3-phosphate dehydrogenase, adenylate kinase, 3-phosphoglycerate kinase and aldolase $(3,9)$. Previously, we have shown that the interaction of CTX with human erythrocytes in plasma extender solution had a non-lytic period during which the membrane structure was weakened and the hydrolysis of phospholipids in the membrane by phospholipase $\mathrm{A}_{2}$ was potentiated (2). (In normal saline a CTX dosage similar to that used in plasma extender solution would conceal this latent period, whereas a reduced dosage would make the hemolysis too slow to follow). In this work we studied the binding characteristics of CTX to intact red blood cell (RBC) and examined the disintegration of the membrane structure by the CTX action, which led to changes in membrane fragility and cell morphology in the non-lytic period.

To whom correspondence should be addressed: Dr. Yee-Hsiung Chen, Institute of Biochemical Sciences, National Taiwan University, Taipei, Taiwan 107. 


\section{Materials and methods}

\section{Materials}

The crude venom of Taiwan cobra (Naja naja atra) was supplied by Chen Hsin Tong Chemical Co., Taipei. CM-Sephadex C-25, Sephadex G-25 and Sepharose 4B were obtained from Pharmacia. Heparin, Tris, $\mathrm{NaDodSO}_{4}$, chymotrypsin and neuraminidase were obtained from Sigma. Iodogen (1,3,4,6-tetrachloro-3 $\alpha, 6 \alpha$-diphenylglycoluril) was obtained from Pierce and $\mathrm{Na}^{125} \mathrm{I}$ from New England Nuclear. Moriamin, a plasma extender, was supplied by China Chemical \& Pharmaceutical Co., Taipei; its composition in $\mathrm{mM}$ was 6.4 $\mathrm{Arg}^{5} \mathrm{BHCl}, 22.6 \mathrm{Gly}, 3.10 \mathrm{His}^{5} \mathrm{BHCl}$ hydrate, 6.87 Ile, 15.6 Leu, 16.9 Lys $^{5} \mathrm{BHCl}$ dihydrate, $8.05 \mathrm{Met}$, 8.79 Phe, 7.56 Thr, 1.47 Trp, 8.55 Val, 0.857 (or $6.00 \%$ ) Dextran T70 and 274 D-sorbitol. All other chemicals were of reagent grade. Water was doubledistilled.

\section{Preparation of CTX}

CTX was isolated from crude snake venom on a CM-Sephadex C-25 column (10). It was iodinated by the chloroglycoluril method $(11,12)$. Twenty $\mathrm{mg}$ of CTX and $5 \mathrm{mCi}$ of $\mathrm{Na}^{125} \mathrm{I}$ in $1.0 \mathrm{ml}$ of $10 \mathrm{mM}$ phosphate buffer ( $\mathrm{pH}$ 7.4) reacted in a vessel, which had been plated with Iodogen, for $20 \mathrm{~min}$ at room temperature. The solution and two rinses of the vessel with the buffer were promptly applied to a CM-Sephadex C-25 column $(1.5 \times 40 \mathrm{~cm})$ preequilibrated with $0.2 \mathrm{M} \mathrm{NaCl}-0.05 \mathrm{M}$ Tris (pH 8.6). The unbound iodide was washed off the column with the Tris buffer. The radioactive fractions on the column were linearly eluted with 0.2 to $0.4 \mathrm{M} \mathrm{NaCl}$ in $0.05 \mathrm{M}$ Tris buffer, collected and desalted on a Sephadex G-25 column.

\section{Preparation of erythrocytes}

Fresh human blood was centrifuged at $1500 \mathrm{~g}$ for $5 \mathrm{~min}$ at $4{ }^{\circ} \mathrm{C}$ to remove the buffy coat. The RBCs were washed at least three times with phosphate-buffered saline at $4^{\circ} \mathrm{C}$ and were used immediately. Cardiotoxin-pretreated erythrocytes (CPEs) were prepared by incubating $0.25 \% \mathrm{RBCs}$ with $7.2 \mu \mathrm{M} \mathrm{CTX}$ in the plasma extender solution for $15 \mathrm{~min}$ at $37^{\circ} \mathrm{C}$ (2). The reaction mixture was diluted with two volumes of cold phosphatebuffered saline. CPEs were collected by centrifugation at $4{ }^{\circ} \mathrm{C}$ and washed twice with the cold saline solution to remove any free CTX.

Intact RBCs were also treated with chymotrypsin to cleave band 3 protein $(13,14)$ or with neuraminidase to remove sialic acid (15) on the external cell surface.

\section{Hemolysis assay}

The hemolysis of $0.25 \% \mathrm{RBC}$ by CTX in plasma extender solution at $37^{\circ} \mathrm{C}$ was followed spectrophotometrically on a Cary 14 spectrophotometer equipped with a jacketed cell holder through which water was circulated to control the temperature (2).

\section{Binding assay}

Aliquots of $0.25 \%$ fresh RBC containing about $2 \times 10^{7}$ cells and appropriate amounts of $1: 9^{125} \mathrm{I}-$ labeled and unlabeled CTX in $1.0 \mathrm{ml}$ of plasma extender solution were incubated at $37^{\circ} \mathrm{C}$ for various times within the non-lytic period in plastic tubes that had been coated with silicone. The cells were collected, washed at least three times each for 15 $\min$ at $4^{\circ} \mathrm{C}$ and broken up in $2 \mathrm{ml}$ of $1 \%$ $\mathrm{NaDodSO}_{4}$. The radioactivity of the hemolyzate was counted in a Packard A5000 gamma counter. The cells were counted in a Coulter ZF- 6 cell counter. Each binding experiment was repeated at least three times and its standard deviation was less than $10 \%$.

One $\mu \mathrm{g}$ of ${ }^{125} \mathrm{I}$-CTX had 84000 to $98000 \mathrm{cpm}$; thus, the 1:9 hot and cold CTX gave 8400 to $9800 \mathrm{cpm}$ per $\mu \mathrm{g}$ of total CTX and was routinely used in the assays. The nonspecifically bound CTX was minor as determined by measuring the counts of a mixture of $10 \mu \mathrm{g} / \mathrm{ml}$ of ${ }^{125} \mathrm{I}$-CTX and $10 \mathrm{mg} / \mathrm{ml}$ of unlabeled CTX that had been incubated with $0.25 \% \mathrm{RBC}$; the counts did not exceed $10-16 \%$ of the total counts of bound CTX obtained with $10 \mu \mathrm{g}^{5} \mathrm{Bml}$ of ${ }^{125} \mathrm{I}$-CTX alone and during the 15-min incubation, there was no hemolysis; see Fig. 1 under Results.

\section{Other analytical procedures}

The lipids in the erythrocyte ghost preparations 
(16) were extracted into $\mathrm{CHCl}_{3}$ (17) and the phosphorous content of the dried lipids was determined (18). Sialic acids in the membrane were liberated by $\mathrm{N}$-acetylneuraminidase digestion (15) and assayed (19). The membrane proteins were determined after the ghosts were solubilized in $1 \% \mathrm{NaDodSO}_{4}(20)$; the ghost proteins were detected by electrophoresis on $3 \%$ polyacrylamide $-0.4 \%$ agarose gels containing $0.2 \% \mathrm{NaDodSO}_{4}$ (21). Once the gels were fixed, stained and destained (22), the Coomassie blue-stained bands were scanned at $560 \mathrm{~nm}$ with a GS 300 desitometer (Hoeffer Scientific Instruments) equipped with a Hitachi recorder. The protein bands were numbered according to convention $(23-25)$.

\section{Results}

\section{Kinetics of hemolysis}

The percent hemolysis of $0.25 \%$ suspension of RBC mediated by CTX at $37^{\circ} \mathrm{C}$ increased with increasing CTX concentration at all times studied. Hemolysis approached a plateau when a concentration of about 7.2 $\mu \mathrm{M}$ CTX was added at each reaction time studied (Fig. 1). Our protocol was therefore to study the events associated with the action of $7.2 \mu \mathrm{M} \mathrm{CTX}$ on $0.25 \% \mathrm{RBC}$ in plasma extender solution at $37^{\circ} \mathrm{C}$, unless stated otherwise. Previously, we reported a non-lytic period of the CTXinduced hemolysis, which decreased with increasing CTX concentration. Under our protocol this latent period lasted about 25 to $30 \mathrm{~min}$ (2). Chymotrypsin- or neuraminidase-treated $\mathrm{RBC}$ had the same latent period as that of intact $\mathrm{RBC}$ (Fig. 2). The kinetics of hemolysis of the enzymetreated and intact RBC also coincided within experimental errors, suggesting no change in hemolysis by cleaving the external polypeptide fragments of band 3 protein or sialic acids from the external surface of the cells.

\section{Binding of CTX to erythrocytes}

${ }^{125} \mathrm{I}-\mathrm{CTX}$ was as active as the unlabeled toxin. At each CTX dosage, the maximum binding of CTX to $\mathrm{RBC}$ at $37^{\circ} \mathrm{C}$ (based on bound ${ }^{125} \mathrm{I}$ bounts) was completed in about $10 \mathrm{~min}$, and was independent of the CTX concentration used (Fig. 3). A plot of the initial rate of binding versus

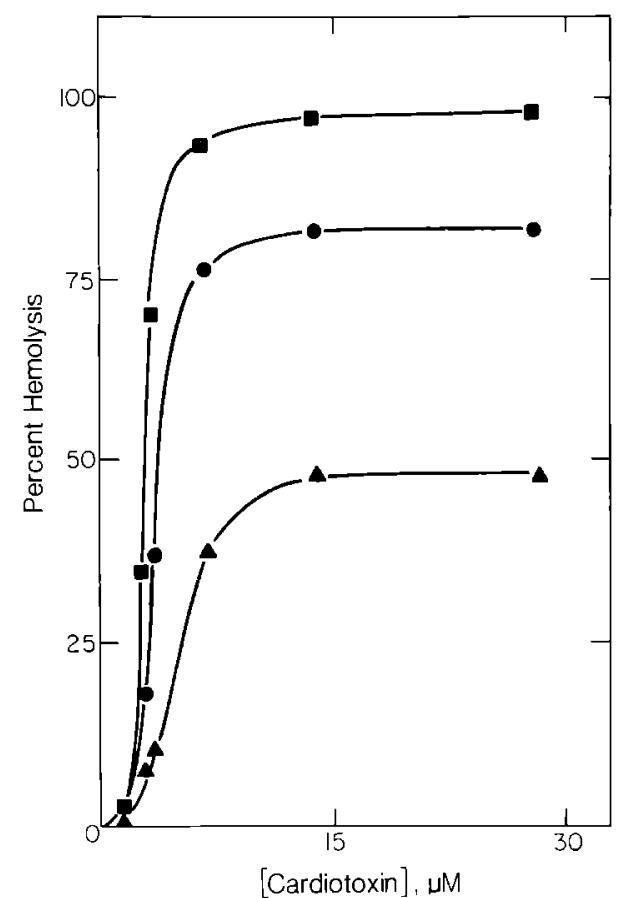

Fig. 1. Hemolysis of $0.25 \%$ (v/v) erythrocytes by cardiotoxin in plasma extender solution at $37^{\circ} \mathrm{C}$. Time of incubation: $\Delta=2 \mathrm{~h} ; \bullet=4 \mathrm{~h} ; \boldsymbol{\square}=6 \mathrm{~h}$.

the CTX concentration was linear with a slope of approximately $0.035 \mu \mathrm{M}$ CTX bound per $\mu \mathrm{M}$ total CTX per min (not shown). The curve gradually leveled off at CTX above $2 \mu \mathrm{M}$ and the rate of binding approached a plateau of about $0.13 \mu \mathrm{M}$ CTX bound per min at $7.2 \mu \mathrm{M}$ total CTX. Essentially the same results were obtained for the interaction of RBC with CTX in the absence and presence of $10 \mathrm{mM}$ inorganic salts (data not shown).

The uptake of CTX by RBC was found almost exclusively in the cell membrane; more than $95 \%$ of the bound ${ }^{125}$ I-CTX could be recovered in the ghost pellets. The ghost proteins could be extracted selectively with $0.5 \%$ Triton X-100 in 56 mM sodium borate at $\mathrm{pH} 8.0(24)$ or with $0.1 \mathrm{~N} \mathrm{NaOH}$ (25), whereas the bound CTX in the cell ghost was nonextractable by either the surfactant or $\mathrm{NaOH}$ and was retained in the ghost residues after extraction. Thus, the toxin bound almost exclusively to the Triton- and $\mathrm{NaOH}$-insoluble portion of the cell membrane. Gel electrophoretic study also indicated that the binding of CTX to RBC did not affect the extraction of ghost proteins by Triton X-100 and $\mathrm{NaOH}$ solutions. 


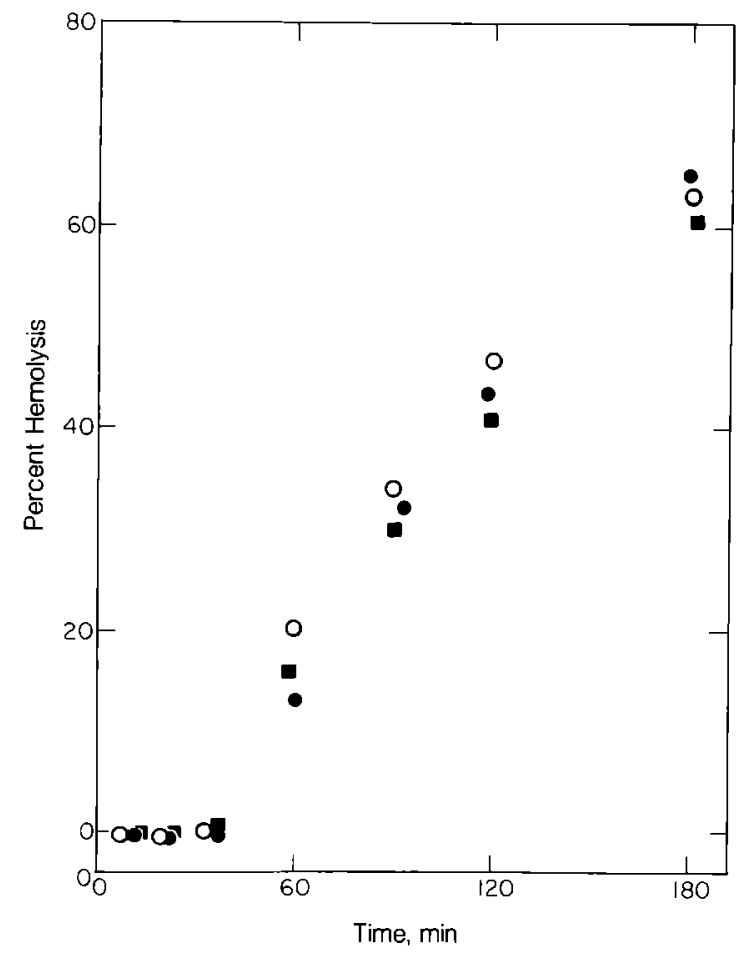

Fig. 2. Kinetics of hemolysis of $0.25 \%$ erythrocytes by $7.2 \mu \mathrm{M}$ cardiotoxin in plasma extender solution at $37^{\circ} \mathrm{C}$. Symbols: - = control RBC; $\bullet=$ chymotrypsin-treated RBC; $\circ=$ neuraminidase-treated $\mathrm{RBC}$.

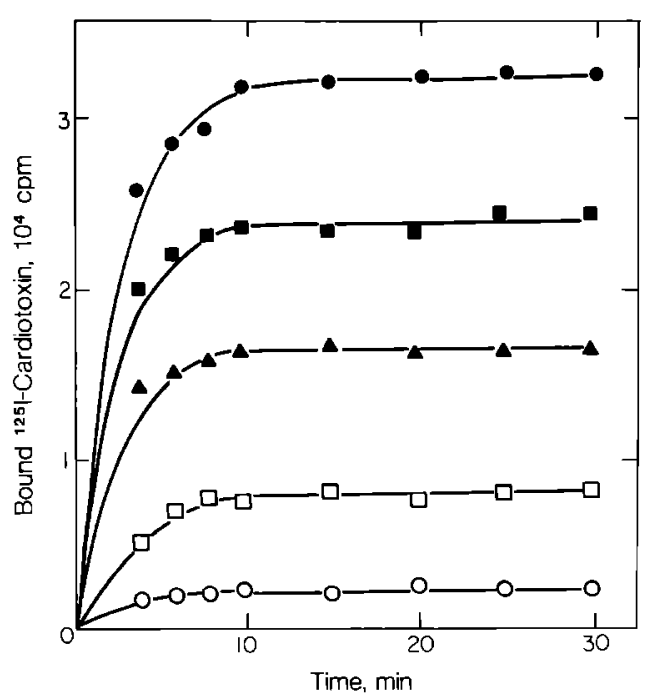

Fig. 3. Time dependence of the binding of cardiotoxin to $0.25 \%(\mathrm{v} / \mathrm{v})$ erythrocytes at $37^{\circ} \mathrm{C}$. Concentrations of CTX in $\mu \mathrm{M}: \quad \circ=0.1 ; \square=0.7 ; \wedge=2.1 ; \square=4.3 ; \bullet=7.2$.

\section{Effect of salt on hemolysis}

The addition of $10 \mathrm{mM}$ inorganic salts considerably inhibited the CTX-induced hemolysis (2). The same was true for the hemolysis of CPE that had been treated with $10 \mathrm{mM}$ inorganic salts (Table 1). The percent hemolysis was significantly reduced in all cases. CPE prepared in the presence of salts seemed to lyse only slightly less than CPE with salts added after its preparation. In the former the salts and unbound CTX were washed off from the collected CPE. Thus, inorganic salts inhibited hemolysis regardless of whether they were added before (and subsequently removed) or after the preparation of CPE.

The degree of binding of CTX to $\mathrm{RBC}$ was slightly reduced by adding $10 \mathrm{mM} \mathrm{NaCl}, \mathrm{KCl}$, $\mathrm{CaCl}_{2}$ and $\mathrm{MgCl}_{2}$, respectively, during the preparation of CPE, but it was unaffected if the salts were added after CPE was prepared (Table 1). The binding was also unaltered by treatment of RBC with chymotrypsin or neuraminidase (data not shown).

\section{Composition of CPE ghosts}

The ghosts prepared from CPE retained about $91 \pm 2 \%$ sialic acid, $87 \pm 3 \%$ lipid phosphorus and $75 \pm 9 \%$ protein of the untreated erythrocytes. The electrophoretic patterns of proteins of CPE and untreated erythrocytes differed in three aspects (Fig. 4). First, the CPE ghost had a large complex containing about $3 \%$ of the bound ${ }^{125}$ I-CTX at the cathodic end of the gel that was absent in the control ghost. Second, bands 1 and 2 (spectrin), band 2.1 (andrin), band 3 and band 5 (actin) in the CPE ghost were considerably smaller than the corresponding ones in the control ghost; $73 \%$ of bands 1 and 2, 84\% of band 3 and nearly all band 4.1 of the control erythrocytes were retained in the CPE ghost, whereas band 4.2 and band 6 (glyceraldehyde-3-phosphate dehydrogenase) were completely lost in the CPE ghost [the bands of proteins were numbered according to Branton (23)]. Third, several fine bands in the band 2 series became more prominent in the CPE ghost than in the control.

\section{Morphology and fragility of $R B C$}

The erythrocytes in plasma extender solution 
Table l. Effect of inorganic salts on the hemolysis of cardiotoxin-pretreated erythrocytes (CPE) and the binding affinity of cardiotoxin (CTX)a.

\begin{tabular}{lcc}
\hline Salt added (10 mM) & $\begin{array}{l}\text { Percent } \\
\text { hemolysis }\end{array}$ & $\begin{array}{l}\text { Relative amount } \\
\text { of bound CTX }\end{array}$ \\
\hline None & $45.4 \pm 5.5$ & $100.0 \pm 4.1$ \\
During CPE preparation ${ }^{\mathrm{d}}$ & $25.3 \pm 2.7$ & $96.9 \pm 1.5$ \\
$\mathrm{NaCl}$ & $25.5 \pm 3.1$ & $95.4 \pm 1.3$ \\
$\mathrm{KCl}$ & $18.6 \pm 0.7$ & $85.8 \pm 3.2$ \\
$\mathrm{CaCl}$ & $20.3 \pm 2.4$ & $83.9 \pm 1.1$ \\
$\mathrm{MgCl}_{2}$ & & \\
$\mathrm{After} \mathrm{CPE} \mathrm{preparation}^{\mathrm{e}}$ & $27.9 \pm 1.7$ & $103.3 \pm 2.0$ \\
$\mathrm{NaCl}$ & $31.7 \pm 3.4$ & $107.0 \pm 4.5$ \\
$\mathrm{KCl}$ & $25.3 \pm 3.1$ & $106.8 \pm 10.6$ \\
$\mathrm{CaCl}$ & $25.0 \pm 0.7$ & $101.6 \pm 3.0$ \\
$\mathrm{MgCl}_{2}$ & \\
\hline
\end{tabular}

a CPE was prepared by incubating $0.25 \% \mathrm{RBC}$ in plasma extender solution with $7.2 \mu \mathrm{M}$ CTX in the non-lytic period for $15 \mathrm{~min}$ at $37^{\circ} \mathrm{C}$ and washed free of unbound CTX.

${ }^{b}$ Incubation of unlabeled CPE suspension for $6 \mathrm{~h}$ at $37^{\circ} \mathrm{C}$; if free CTX was not washed away, the percent hemolysis was close to 100 (see Fig. 1).

c Incubation of labeled CPE suspension for $15 \mathrm{~min}$ at $37^{\circ} \mathrm{C}$.

$d$ The plasma extender solution in footnote a contained $10 \mathrm{mM}$ salt.

e CPE in footnote a was resuspended in plasma extender solution containing $10 \mathrm{mM}$ salt.

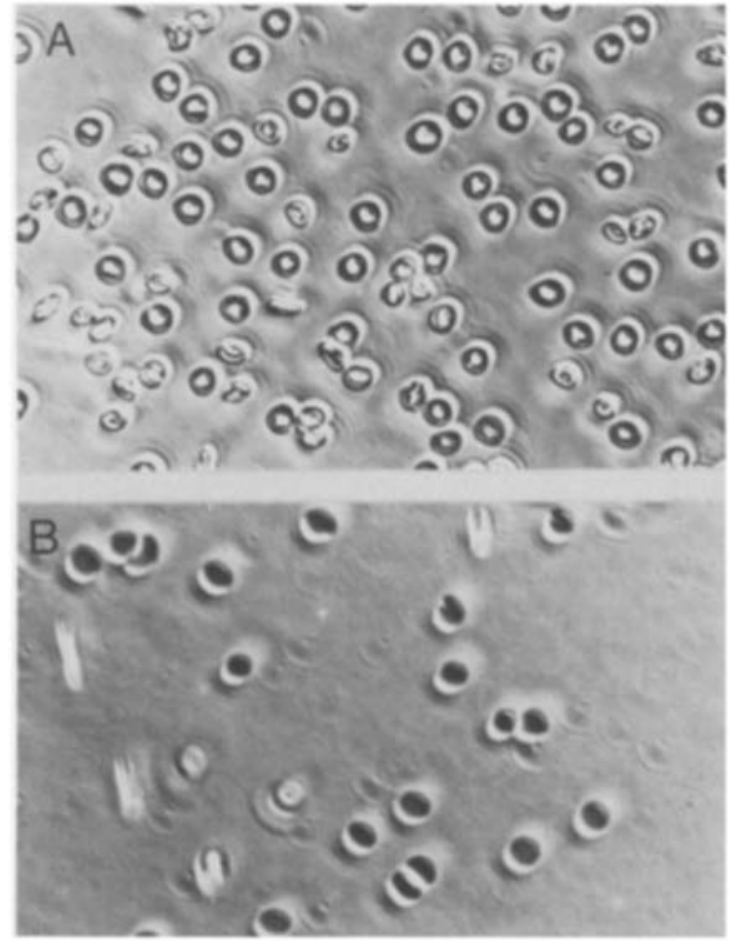

Fig. 5. Phase contrast micrography of (A) intact erythrocytes and (B) cardiotoxin-pretreated erythrocytes.

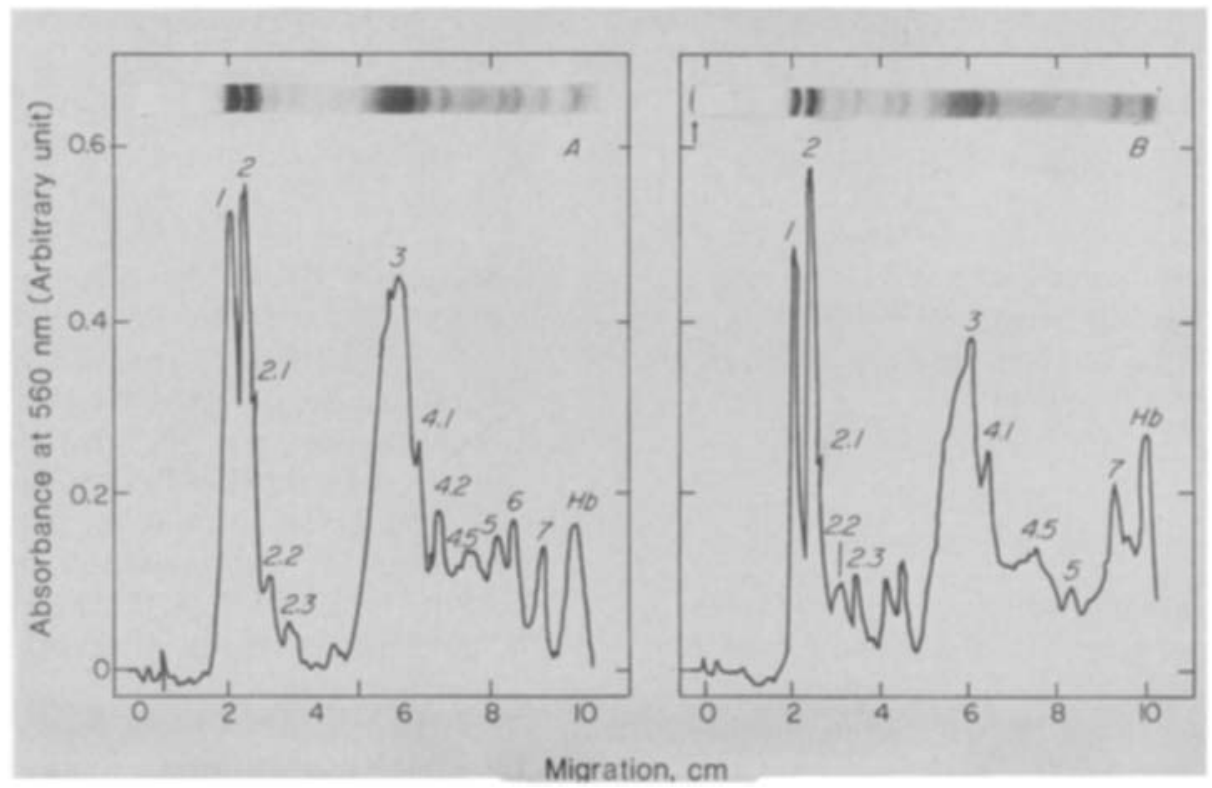

Fig. 4. $\mathrm{NaDodSO}_{4}$-polyacrylamide-agarose gel electrophoresis of proteins in erythrocyte ghosts. Patterns: (A) control RBC and (B) cardiotoxin-pretreated erythrocytes (both having an equal number of cells). The bands are numbered according to Branton (23). The arrow indicates protein aggregates of cardiotoxin-pretreated erythrocytes. 


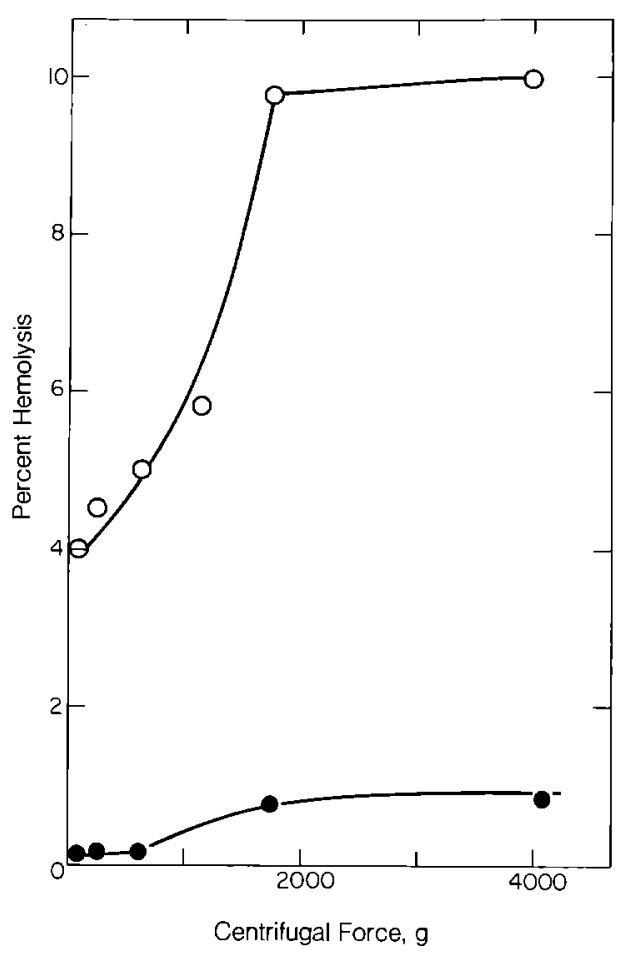

Fig. 6. Percent hemolysis of erythrocytes after sedimentation at $4^{\circ} \mathrm{C}$. Symbols: $\bullet=$ control erythrocytes; $0=$ cardiotoxinpretreated erythrocytes.

were discoid-shaped (Fig. 5A) and were converted to smooth spheres in the presence of CTX (Fig. 5B). Further, CPE was more fragile and less resistant to mechanical friction than untreated $\mathrm{RBC}$ and it was easily broken up under centrifugal forces (more than $600 \mathrm{~g}$ ) (Fig. 6). However, the disintegration of cells could be avoided if two volumes of cold phosphate-buffered saline were added to one volume of the more viscous plasma extender solution before sedimentation.

\section{Discussion}

CTX was almost exclusively attached to the membrane of intact RBC as evidenced by more than $95 \%$ recoverable CTX associated with the ghost; it may not penetrate the plasma membrane and enter the cytoplasm. The CTX-RBC interaction led to structural changes in the cell membrane, as is evident from morphology (Fig. 5) and fragility (Fig. 6) studies. The binding of CTX to RBC differs from that to the membrane of other types of cells; for instance, the slow binding requiring about 10 min (Fig. 3) contrasts the rapid binding of isolated axonal membrane (26). The binding was also unaffected by the presence of inorganic salts (Table 1); this again contrasts the inhibition of the CTX binding to heart cell membrane by high concentration of sodium or calcium ions (27).

Spectrin (bands 1 and 2) and actin (band 5) are two major proteins of the membrane skeleton, which form cytoskeleton networks. A fraction of band 3 protein attached to the shell of membrane skeleton forms a tertiary complex with band 2.1 and 4.2 proteins $(28-32)$. Band 6 protein binds electrostatically to a polyacidic region of band 3 protein (33) (this study used isolated ghost) and is also believed to bind to F-actin and the actin-spectrin complex. During the preparation of CTE ghosts, a considerable portion of band 2.1 protein, $16 \%$ of band 3 protein and nearly all band 4.2 and 6 proteins were liberated under a strong centrifugal force (39000 g) (Fig. 4). Concomitant removal of these four proteins implies that the CTX action may weaken the in situ attachment points that connect the lipid bilayer of the membrane and integral proteins to the cytoplasmic shell. The CTX action does not seem to affect the binding affinity of band 4.1 protein to the membrane skeleton (the CPE ghost retained nearly all of this protein).

CTX caused the appearance of aggregates containing $3 \%$ of the bound CTX at the cathodic end of electrophoretic gel (Fig. 4). We suspect that this complex may be the aggregates of spectrin and actin by direct action of the basic CTX on the cytoskeleton of RBC. This is in line with the reduction of band 1, 2 and 5 proteins in CPE (Fig. 4) and also the fact that basic polypeptides can precipitate an extractable mixture of spectrin and actin and contract the intact spectrin meshwork (34). This tentative conclusion must be confirmed by future studies. The formation of aggregates could not be attributed to the $\mathrm{Ca}^{2+}$-mediated crosslinking of erythrocyte proteins $(35,36)$ because the action of CTX on RBC proceeded in a medium devoid of any inorganic salts.

Since the bound CTX was recoverable in the Triton-insoluble shells and it was unaffected by chymotrypsin digestion of RBC (although the cleaved fragment may remain membrane-bound and probably still associated), the binding of CTX 
to the external fragment of band 3 protein can be ruled out. Likewise, removal of sialic acid residues of the glycoprotein on the outer cell surface with neuraminidase did not affect the CTX binding (data not shown).

Triton X-100 preferentially releases from ghost cells all glycerides and glycoproteins, including those that can be stained by the periodic acid-Shiff reagent, phosphatic acid, lysophosphatidylcholine and phosphatidyl serine $(24,25)$. A large portion of band 4.2 and 6 proteins and more than $60 \%$ of band 3 protein were also extractable by this surfactant. The membrane skeleton, i.e. the Tritoninsoluble residues, retained a certain amount of lipids and proteins, mainly band 1, 2, 4.1 and 5 proteins forming a basic complex of cytoskeleton. The lipids contained about $34 \%$ phosphatidylcholine, $27 \%$ phosphatidylethanolamine, $3 \%$ phosphatidylserine, $83 \%$ sphingomyelin and $40 \%$ cholesterol of the intact membrane. On the other hand, the $\mathrm{NaOH}$ solution liberated those proteins in the Triton-insoluble residues, but not lipids. The fact that the bound CTX on RBC could not be liberated by either the Triton X-100 solution or $0.1 \mathrm{M} \mathrm{NaOH}$ suggests that the lipids in the membrane skeleton may provide most of the binding sites. If this is the case, lack of inhibition by inorganic salts for the CTX binding implies a hydrophobic interaction in the nonpolar domain of the skeleton lipids [it is noted that CTX maintains its conformation in solvents less polar than water (37) and can intercalate into the lipid layer $(7,8)$ ]. Because the bound CTX can interact with CTX antibody (2), most binding sites may reside in the nonpolar region of the outer lipid bilayer of the membrane skeleton, where phosphatidylcholine and sphingomyelin are mainly located (38). The binding of basic CTX molecules to the outer lipid bilayer will affect an electrostatic repulsion and may cause the cell to expand and transform the cellular shape (Fig. 5). This in turn could decrease the in situ interaction between lipid and protein molecules in the intrinsic domain of the membrane and weaken their attachment to the membrane. The loosening of several band proteins from the cell membrane by the CTX action also seems to support this explanation. Inorganic salts and CTX antibody may shield the charges on CTX molecules and diminish electrostatic repulsion. Thus, these compounds may be partly responsible for their inhibitory effect on the CTX-induced weakening of the membrane (2).

Alternatively, CTX may make small holes in the membrane bilayer, which exclude sorbitol and Dextran more than saline. The cells would then slowly swell and lyse by a colloid-osmotic mechanism; that is, such small holes allow microsolutes to equilibrate but retain hemoglobin and its counterions within the cell as a fixed unbalanced osmotic load. This hole model has recently been proposed for the study of the interaction of chloropromazine with erythrocyte membrane (39). However, there is a major difference in the hemolytic activity between chloropromazine and CTX. Chloropromazine, which is also basic, lyses the cells even at $0-4^{\circ} \mathrm{C}$, whereas CTX did not below $20^{\circ} \mathrm{C}$ (2). The colloidosmotic mechanism would also favor hemolysis upon the addition of inorganic salts, whereas our results seemed to suggest an inhibitory effect of inorganic salts.

In this work RBC was suspended in plasma extender solution instead of saline buffer for reasons mentioned previously (2). Most important, the non-lytic period of RBC was prolonged so that the intermediate events leading to cell lysis could be examined. The observed discoid-shaped cells were identical with those found in whole blood (data not shown). However, it is possible that our results could differ somewhat from those under physiological condition, but the events associated with the CTX action should remain unaffected.

\section{Abbreviations}

CTX: cardiotoxin; CPE, cardiotoxin-pretreated erythrocyte; RBC, red blood cell.

\section{Acknowledgments}

This work was supported by grant NSC74-0203-B001-02 from the National Research Council, Taiwan, China and in part by United States Public Health Service Grant GM-10880-26.

\section{References}

1. Chang CC: The action of snake venom on nerve and muscle. In: Lee CY (ed). Handbook of Experimental Pharma- 
cology, Vol. 52. Springer-Verlag Berlin, Heidelberg Press, 1979, pp $309-376$.

2. Chen YH, Hu CT, Yang JT: Membrane disintegration and hemolysis of human erythrocytes by snake venom cardiotoxin (a membrane-disruptive polypeptide). Biochem Int $8(2): 329-338,1984$.

3. Condrea E: Hemolytic effects of snake venom. In: Lee CY (ed). Handbook of Experimental Pharmacology, Vol. 52. Springer-Verlag Berlin, Heidelberg Press, 1979, pp $448-472$.

4. Tu A: Nonneurotoxin basic proteins (cardiotoxins, cytotoxins, and others). In: Venoms: Chemistry and molecular biology. John Wiley \& Sons, New York, 1977, pp 301-320.

5. Yang CC: Chemistry and evolution of toxins in snake venoms. Toxicon 12:1-43, 1974.

6. Chen YH, Pan BT, Lee CP: The hydrogen ion titration of Taiwan cobra neurotoxin and cardiotoxin. Biochim Biophys Acta 702:193 - 196, 1982.

7. Bougis $\mathrm{P}$, Rochat $\mathrm{H}$, Pieroni G, Verger R: Penetration of phospholipid monolayers by cardiotoxins. Biochemistry 20:4915 - 4920, 1981.

8. Chen YH, Lai MZ, Kao LS: Destruction of liposome vesicles by Taiwan cobra cardiotoxin. Biochem Int 3(4):385-390, 1981.

9. Condrea E: Membrane-active polypeptides from snake venom: cardiotoxins and haemocytotoxins. Experientia $30: 121-129,1974$.

10. Lo TB, Chen YH, Lee CY: Chemical studies of Formosan cobra (Naja naja atra) venom. Part 1. Chromatographic separation of crude venom on CM-sephadex and preliminary characterization of its components. J Chinese Chem Soc 13:25-37, 1966.

11. Fraker PJ, Speck JC Jr: Protein and cell membrane iodinations with a sparingly soluble chloromide, 1,3,4,6-tetrachloro-3 $\alpha, 6 \alpha$-diphenylglycoluril. Biochem Biophys Res Commun 80:849-857, 1978.

12. Markwell MAK, Fox CF: Surface-specific iodination of membrane proteins of viruses and eucaryotic cells using 1,3,4,6-tetrachloro-3 $\alpha, 6 \alpha$-diphenylglycoluril. Biochemistry 17:4807-4817, 1978.

13. Dupre AM, Rothstein A: Inhibition of anion transport associated with chymotryptic cleavages of red blood cell band 3 protein. Biochim Biophys Acta 646:471-478, 1981.

14. Steck TL, Ramos B, Strapazon E: Proteolytic dissection of band 3 , the predominant transmembrane polypeptide of the human erythrocyte membrane. Biochemistry 15:1154-1161, 1976.

15. Seaman GVF, Knox RJ, Nordt FT, Regan DH: Red cell aging. I. Surface charged density and sialic acid content of density-fractionated human erythrocytes. Blood 50:1001-1011, 1977.

16. Steck TL, Weinstein RS, Straus JH, Wallach DFH: Insideout red cell membrane vesicles: preparation and purification. Science 168:255-256, 1970.

17. Wintrobe ML: Clinical Hematology. Lea and Febiger, Philadelphia, 1974, p 96.

18. Lebel D, Poirier GG, Beaudoin AR: A convenient method for the ATPase assay. Anal Biochem 85:86-89, 1978.

19. Warran L: The thiobarbituric acid assay of sialic acids. J Biol Chem 234:1971-1975, 1959.
20. Lowry OH, Rosebrough NJ, Farr AL, Randall BJ: Protein measurement with the Folin reagent. J Biol Chem 193:265-275, 1951 .

21. Steck TL: Cross-linking the major proteins of the isolated erythrocyte membrane. J Mol Biol 66:295-305, 1972.

22. Fairbanks G, Steck TL, Wallach DFH: Electrophoretic analysis of the major polypeptides of the human erythrocyte membrane. Biochemistry 10:2606-2617, 1970.

23. Branton D, Cohen CM, Tyler T: Interaction of cytoskeletal proteins on the human erythrocyte membrane. Cell $24: 24-32,1981$

24. Yu J, Fischman DA, Steck TL: Selective solubilization of proteins and phospholipids from red blood cell membranes by nonionic detergents. J Supramol Struct 1:233-248, 1973.

25. Steck TL, Yu J: Selective solubilization of proteins from red blood cell membranes by protein perturbants. J Supramol Struct 1:220-232, 1973.

26. Vincent JP, Schweitz H, Chicheportiche R, Fosset M, Balerna M: Molecular mechanism of cardiotoxin action on axonal membranes. Biochemistry 15:3171-3175, 1976.

27. Tonsing L, Potgieter DTJ, Louw AI, Visser L: The binding of snake venom cardiotoxins to heart cell membranes. Biochim Biocphys Acta 732:282-288, 1983.

28. Haest CWM: Interactions between membrane skeleton proteins and the intrinsic domain of the erythrocyte membrane. Biochim Biophys Acta 694:331-352, 1982.

29. Bennett V, Stenbuck PJ: The membrane attachment protein for spectrin is associated with band 3 in human erythrocyte membranes. Nature 280:468-473, 1979.

30. Steck TL: The organization of proteins in the human red blood cell membrane. J Cell Biol 62:1 - 19, 1974.

31. Sheetz MP: Integral membrane protein interaction with triton cytoskeletons of erythrocytes. Biochim Biophys Acta $557: 122-234,1979$.

32. Bennett V, Stenbuck PJ: Human erythrocyte ankyrin. J Biol Chem 255:2540-2548, 1979.

33. Tsai I-H, Murthy SNP, Steck TL: Effect of red cell membrane binding on the catalytic activity of glyceraldehyde-3-phosphate dehydrogenase. J Biol Chem 257:1438-1442, 1982.

34. Elgsaeter A, Shotton DM, Branton D: Intramembrane particle aggregation in erythrocyte ghosts. II. The influence of spectrin aggregation. Biochim Biophys Acta 426:101 - 122, 1976.

35. Carraway KL, Triplett RB, Anderson DR: Calciumpromoted aggregation of erythrocyte membrane proteins. Biochim Biophys Acta 379:571 - 581, 1975.

36. Lorand L, Weismann LB, Epel DL, Bruner-Lorand J: Role of the intrinsic transglutaminase in the $\mathrm{Ca}^{2+}$-mediated crosslinking of erythrocyte proteins. Proc Natl Acad Sci USA 73:4479-4481, 1976.

37. Hung MC, Chen YH: Conformational stability of a snake cardiotoxin. Int J Peptide Protein Res 10:277 - 285, 1977.

38. Op den Kamp JAF: Lipid asymmetry in membranes. Ann Rev Biochem 48:47-71, 1979.

39. Lieber MR, Lange $Y$, Weinstein RS, Steck TL: Interaction of chlopromazine with the human erythrocyte membrane. J Biol Chem 249:9225-9234, 1984

Received 14 July 1986 